\title{
WTO, A Multilateral Trade Institution or a Parallel Organisation: Reform Initiatives Addressing the WTO Agricultural Trade Distortions to Developing Countries
}

\author{
By Isaac O. C. Igwe*
}

The World Trade Organisation (WTO) process and its ethos are fast losing their development objectives. The crisis, challenges and complexities in the implementation of WTO policies on agriculture and market access has not abated. Intellectuals, researchers and academics opine that the implementation of WTO policies have not only encouraged power and development divide between the Industrialised nations and the developing nations, it has worsened the rate of global economic inequality. Although the inclusion of agriculture in the Uruguay Round was taken as a major achievement, the commitment to minimum market access for most protected products, reducing export subsidies and a considerable measure of support, did not do much to lower agricultural protection. The promises made to the developing countries under the Doha Development Agenda (DDA) on agriculture, market access, reduction of subsidies/tariffs and implementation issues were limited and not fulfilled. Can the emerging WTO market capacities and alliances lead to a change in the decision-making process? This writing aims to critically analyse the existing WTO legal problems hindering market flows and the incidence of barriers to trade in agriculture being much higher than protection of developing countries farmers which has impacted their development.

Keywords: WTO; Legal; Agriculture; Implementation; Inequality; Developing Countries; Doha Development Agenda; Decision-marking; Market Access; Development.

\section{Introduction}

The past Sixty years have witnessed opportunities and challenges to attempts to structure coherent international economic relations. The developing countries have perceived the Uruguay Round of the General Agreement on Tariffs and Trade (GATT) as failing in its promise to improve on United States unilateralism. ${ }^{1}$

\footnotetext{
LLB (Hons), Barrister \& Solicitor Supreme Court of Nigeria, LLM, Ph.D. (Law), Birkbeck, University of London, London, UK. Email: isaacigwe@ hotmail.com

*LLB (Hons), Barrister \& Solicitor Supreme Court of Nigeria, LLM, Ph.D. (Law), Birkbeck, University of London, London, UK.

Email: isaacigwe@hotmail.com
} 
The devolution of multilateralism to regional and bilateral bases, precipitated by the US in the Uruguay Round dispute settlement rules, has led to a parallel organisational structure in the WTO, such that parties exploit the legal loopholes in the system and used it to block consensus on contentious aspects of the organisation. ${ }^{2}$ Originally this structure existed as a neoliberal regime in Britain and the United States with the emergence of 'Washington Consensus', which shrouded the aim of developmentalism and substituted it with globalisation informed by tireless increase of the asymmetrical part played by WTO, IMF and the World Bank in global economy. ${ }^{3}$ The GATT was mainly a creation of the United States and its western allies, structured mostly for trade profit against economic development which was the ultimate concern of the developing countries of Africa, Asia and South America. ${ }^{4}$ Potentially, less attention has been given to the WTO's role in promoting trade and trade-related policy to favour developing countries' development by reducing tariff and non-tariff import barriers or eliminating protectionism in export markets. ${ }^{5}$ More barriers were created for products potentially frequently exported by developing countries, compared to the reduced tariff barriers on goods of export interest to the developed countries. ${ }^{6}$ This practice obliterated the market access obligation enshrined in the WTO Agreement as the outcome benefits shared were not balanced. ${ }^{7}$ After the Uruguay Round Agreement, the interests of the developing countries were not fully protected but worsened, as the export interests of the developing countries still faced numerous barriers which discouraged the manufacture of domestic products and prevented the development of their infant industries. Coincidentally, they were faced with the option of allowing imports from the industrialised countries which ultimately led to a flood of unwarranted products that often triggered anti-dumping legislation. ${ }^{8}$ By and large, high tariffs were often concentrated around agriculture, textiles and clothing, which effectively generated foreign currencies to the

\footnotetext{
${ }^{1}$ See Bello, Cunningham \& Rau. (1994). n relation to TRIPs, the developing countries demanded that the unilateral or bilateral application of intellectual property disputes must be put to an end. Brazil thought that the multilateral trade rules of GATT was structured to shield weak to stronger exporters from 'unilateral discrimination and harassment'. The US special legislation Section 301 did nothing less than frustrate trade negotiations in the GATT. See Stewart (1999) at 157-574.

${ }^{2}$ See Barton, Goldstein, Josling \& Steinberg (2006).

${ }^{3}$ See Igwe (2019).

${ }^{4}$ See Bergsten (1998).

${ }^{5}$ See Milner (2006).

${ }^{6}$ The post-war multilateral trading system did not contemplate the interest of the developing countries. It was instituted as the basis of power relationships between the rich countries, most especially the EU and US. For this reason, it was more interested in the developed countries' markets than the developing countries. Thus the hallmark of the European Common Market towards the end of 1950s strengthened the American admittance to entertain the Kennedy Round of the 1960s; See Bergsten (1998).. This was informed by the idea to reduce the existing discrimination against US exports and as well build the 'new Atlantic partnership' articulated by President Kennedy. At this time, there was a monetary crisis in the US which led to balance-ofpayment problems and President Kennedy clinched on access to foreign markets for American exports as a way out; See also Stiglitz \& Charlton (2005)..

${ }^{7}$ See Watal (2000). For the asymmetrical benefits in the market access obligation in the WTO Agreement see Bhagirath (1998).

${ }^{8}$ See WTO (1994a).
} 
developing countries through their exports. As a result, the developing countries pursued a trade policy of Import Substitution Industrialisation (ISI), which used high protective tariffs to compel consumers to buy domestically made products at the expense of imports. Besides, the tariff peak influenced the governments of the developing countries to create trade policies aimed at self-sufficiency and to ask for 'Special and Differential Treatment' (SDT), in the GATT negotiation instead of accepting the multilateral rules of the GATT based on reciprocity. ${ }^{10}$

Although the GATT system progressed, it turned out that the major threat to that system was its lack of relevance to traders and governments in the developing world. With the focus of the Uruguay Round and its agenda in mind, the developing countries argued that the developed countries did not honour their traditional goods such as textiles and agriculture and seeking for further liberalisation in those areas would be a precondition to any new negotiation. ${ }^{11}$ However, in the 1980s, there was a major surge in the developing countries' active engagement in the Uruguay Round. This was as a result of market-based economic reforms in many developing countries in the 1980s which encouraged their governments to pursue more positively the market-based principles and objectives of GATT. ${ }^{12}$

It is obvious that these changes were as a result of pressure from both the developed countries and international institutions for developing countries to liberalise their economies. In addition, the collapse of communism and the clear success of free market activities in countries such as Singapore and Taiwan resulted in a revolution in internal policy in a number of countries. ${ }^{13}$ For instance, the deep financial crisis of India in 1991 led to its economic reforms structured to deregulate the national economy and enhance its economic efficiency. ${ }^{14}$ India, like most developing countries, revised its opposition stance to the Uruguay Round and supported the multilateral agreement ${ }^{15}$. The Uruguay Round trade negotiations changed the face of international dispute settlement by creating the $\mathrm{WTO}^{16}$, which

\footnotetext{
${ }^{9}$ See for the reasons why the SDT was opted for: The developing countries felt that there was need for special and differential treatment to enhance their terms of trade, curb their dependence on exports of primary commodities, and foster industrialisation through the protection of infant industries. See Gibbs (1998). They were later provided with differential treatment under Article XVIII of the GATT rules inter- alia it exempted economies 'which can only support low standards of living and are in the early stages of development...implement programmes and policies of economic development designed to raise the general standard of living of their people, to take protective or other measures affecting imports'. This status allows the developing countries to be members of the GATT and also avoid the obligations imposed on the developed nations. Moreover Article XVII gives them the liberty to choose a development policy of their choice but limits their power within the actual GATT negotiations.

${ }^{10}$ See for a demonstration of the advantages of protectionist measures which have been previously tested by the industrialised countries during their development stage of the $19^{\text {th }}$ and $20^{\text {th }}$ century. See Khor (2001) at 16-38.

${ }^{11}$ See Finger (2007).

${ }^{12}$ See Winham (1998).

${ }^{13}$ See Bello, Cunnigham \& Rau (1994).

${ }^{14}$ Ibid.

${ }^{15}$ Ibid.

${ }^{16}$ See Hudec (1999).
} 
took the place of the flawed GATT regime. ${ }^{17}$ The WTO created a more rule based dispute resolution process ${ }^{18}$, which sought to reduce the prolonged delay or absence of compliance for which the 1947 GATT dispute settlement mechanism was noted. ${ }^{19}$ The aim of instituting the WTO was to liberalise international trade and ensure economic growth and development, mostly for the developing countries. This had been the intent of the 1947 GATT preamble which provided that:

"trade and economic endeavour should be conducted with a view to raising standards of living, ensuring full employment and a large and steadily growing volume of real income $[\ldots]^{, 20}$

The organisation was originally set up to be a democratic institution, but it is controlled by the industrialised nations or their corporations. WTO is focused towards a jet-speed trade liberalisation, apparently in the areas and products of interest to the most powerful in the institution. Third World countries are conspicuously marginalised when it comes to the implementation of WTO rules, which has obviously been a point of discussion and perplexity. ${ }^{21}$

Developing countries accepted the Uruguay round agreement, believing that they would benefit from agricultural liberalisation and subsidy reduction in the Organisation of Economic Cooperation and Development (OECD) countries under the Agreement on Agriculture. Instead, they faced unfair trade as dumped and subsidised products flooded their local markets. Trade liberalisation created problems rather than eliminating them. ${ }^{22}$ The Doha round commenced with a ministerial meeting in Doha, Qatar, in 2001. This was followed by the ministerial meeting in Cancun, Mexico in 2003. In 2005 the Hong Kong ministerial was held. Similar negotiations were held in Geneva, Switzerland in 2004, 2006 and 2008; in Paris France, in 2005, and in Potsdam, Germany in 2007. Doha, since launched, has not achieved a remarkable development impact in the rural development circle. This, no doubt, has worsened the extent of poverty in the developing countries. After more than half a century of trade liberalization, negotiations are often based on complex issues. ${ }^{23}$ To date, the WTO has not achieved a coherent agreement in its negotiations, satisfactory to the developing countries (DCs) and Least Developed Countries (LDCs) members. The WTO Doha Development Agenda's negotiation of July 23-29, 2008 broke down after it failed to reach an agreement on agricultural import rules, ${ }^{24}$ such as tariffs, non-tariff barriers, services and trade remedies. ${ }^{25}$ As a result of the breakdown, it was argued that no

\footnotetext{
${ }^{17}$ Ibid.

${ }^{18}$ See GATT (1994b) and See WTO (1996).

${ }^{19}$ See Khansari (1996) at 189.

${ }^{20}$ See GATT (1947).

${ }^{21}$ See Igwe (2019).

${ }^{22}$ See FAO (2000).

${ }^{23}$ See Miller \& Markheim (2008).

${ }^{24}$ See BBC (2009).

${ }^{25}$ See Fergusson \& Ian (2008).
} 
substantive negotiations could be held in the near future. ${ }^{26}$ Although emergency negotiations were held by the USA, India and China towards the end of 2008 to agree on negotiation principles, they did not result in any progress. ${ }^{27}$ Paradoxically, in trade negotiations, countries can eliminate their tariffs, only if others take the same step. $^{28}$ The WTO members, especially the developed nations, can open their markets only as a concession. It is clear that the Doha development Agenda (DDA) is not working and should be reformed. It will be argued in this treatise that the WTO principle should include mutually gainful transactions and a non-coercive trade regime of negotiations. Democracy in the WTO process is like a skilful and prolonged public relations exercise by the developed countries and the WTO Secretariat. Recent reflections on the nature of WTO methods of decision-making leave the DCs marginalised and call for an institutional reform. Scepticisms are rife as to whom the WTO is really accountable and the deep rooted democratic deficit of the organisation. The writing will focus on the legal aspects of some problematic and essential agreements of the WTO in connection with development as applied to developing countries. The central argument here is that the standard operating procedures of the WTO are a reflection of power imbalance between the industrialised nations and developing nations which worsens the rate of inequality and demands justice. This writing will critically analyse the results of the Uruguay round and evaluate its effect on such issues as agriculture, and decision making. The writing will look into the implementation problems that developing countries face in the GATT/WTO. This will entail an examination of implementation theory and linking it to issues of legitimacy. It will explore the issues of negotiating plans, evolution of decision making and the role of collective action among the developing countries. The treatise will conclude by advocating that the developing countries should join together and stand up to the bullying of the developed nations. Finally, a development based approach will be advocated, aiming to respect national sovereignty but not to be used as a factor for economic domination.

\section{Policy Implementation}

The WTO implementation of policies presents a deeply embedded obstruction to the means by which developing countries can improve their economic situation. History has it that Agricultural trade liberalisation began in 1947 with 23 major trading nations meeting in Geneva followed by formation of GATT. This led to successive initiative to liberalize world trade but agricultural products liberalization excluded temperate-zone of developing countries using Industrialised countries as the mainstream of liberalisation. The first attempt to set right global agricultural trade production policies was carried out in the Uruguay Round (1986-94), which formed the Marrakesh Agreement establishing the World Trade Organisation with Agreement on Agriculture as an integral part. Serious deficiencies and imbalances

\footnotetext{
${ }^{26}$ See Beattie (2008).

${ }^{27}$ Ibid.

${ }^{28}$ See Deardoff (2007).
} 
in the implementation of WTO agreements have resulted in grave problems for developing countries who are subjected to the decisions of the Industrialised countries reached in the Ministerial Conferences. Agriculture is very important to the DCs, especially the LDCs as their livelihood depends on farming. The DCs/LDCs are highly dependent on agriculture as they have large population and does not have financial resources to subsidize agriculture as most of them are outside the OECD countries. The Industrialized countries receive policies with some level of support and protection against the developing countries counterparts and this leads to economic distortions. Specific attention was devoted to these issues during the WTO 1998-1999 Ministerial Conference in Seattle. ${ }^{29}$ About a hundred proposals were registered and presented, but the participants did not come to a unanimous conclusion. ${ }^{30}$ Some of the suggestions were for changes in practice whereas others were for improvements in the rules themselves. Two years later, WTO members launched Doha negotiations in September 2001 which met some difficulties where the developing countries made a concerted effort for the implementation of agricultural policies in the Doha Ministerial Conference. They argued that the issues introduced were within the existing agreement; hence their resolution deserved higher priority over the introduction of new issues. In the end, on seeing the stubborn stand taken by the developing countries on these issues, the developed countries conceded to the pressure, but treated these issues in the most cavalier manner such that they were not treated at all. ${ }^{31}$ Hence, the Doha Ministerial Declaration says:

"We attach the utmost importance to the implementation-related issues [...] and are determined to find appropriate solutions to them". ${ }^{32}$

In some developing countries, mostly in Africa, liberalisation in the industrial sector by reducing tariffs and removing non-tariff measures proceeded under concerted pressure from International Financial Institutions (IFI). When countries reduced their tariffs as a result of these structural adjustment programmes, they would be encouraged to bind themselves to the reduced tariff in the WTO. By doing so, they would be prevented from raising the tariff in future even if they ceased to need assistance from the IFIs. ${ }^{33}$ The right structures in the WTO with trade liberalisation as its ethos means a successful realisation of its goals enshrined in the GATT 1947 agreement and amplified in the WTO Marrakech Agreement that relations in the field of trade and economic endeavour should be conducted with a view to raising standards of living. ${ }^{34}$ The preamble recognised that international trade regulation represents competing interests. The power of the multilateral trading system relies upon this constitutional structure and procedure. There are complexities in these provisions as they are of a constitutional nature and raise institutional problems relating to international and domestic law. The

\footnotetext{
${ }^{29}$ See Bhagirath (2003) at 105.

${ }^{30}$ See WTO (2001a).

${ }^{31}$ See Bhagirath (2003) at 105.

${ }^{32}$ See WTO (2001b)

${ }^{33}$ Ibid.

${ }^{34}$ WTO (1994). [hereinafter Marrakesh Agreement].
} 
WTO lacks mutual relationships in both political and judicial processes. Some of the issues at stake are the actual role of the secretariat which entails its involvement in decision-making, the function of stakeholders, the relationship of trade rounds and law making. There are horizontal problems such as marginalisation and clarity in dealing with other international organisations and application of international law. Whilst vertically, the connections between WTO law and domestic law, the effect of WTO law in trade policy formulation, implementation and enforcement within members are at stake. This includes the connections between WTO law, regionalism and preferential trade that operate under the multilateral structure but often experience non-compliance with WTO rules.

There have been numerous underlying institutional issues in the WTO which members have not thoroughly addressed. These include 'how can we achieve better policy coordination in addressing borderline issues among trade and other fields governed by other institutions such as culture, human rights, investment protection, finance, monetary affairs and development assistance; 'how do we make sure that WTO rules are taken seriously at home by legislators and domestic courts alike?' and 'how can we, in turn, assure that rule-making responds to the needs for transparency, accountability and legitimacy? ${ }^{35}$ Despite the challenges militating against progress, the WTO's contracting members are reluctant to address them. Although there have been some studies responding to such problems, they have not been taken seriously. Besides, the proposal to create a committee or working group to deal with institutional issues at the WTO has not been accepted. ${ }^{36}$ Since 2001, within the Doha development agenda, the only area of institutional issues discussed has been the reform of dispute settlement in the context of preferential agreements to improve transparency. ${ }^{37}$ The main essence of the Uruguay round agreement was agreed by the US and the EU and thereafter given a multilateral scope. Other member states played an important but nondecisive role.

With the advent of rising economies, the WTO faces a multi-polar world. Since the Cancun conference, major WTO decisions require the consent of emerging economies such as Brazil and India. Although China prefers a discrete voice in negotiations, no major multilateral trade decision takes place without its consent. The recent shift in WTO multilateral trade decision-making processes was as a result of the increased participation of medium-sized and small countries in negotiations, operating in a context of interest-driven coalition building. ${ }^{38}$ Nonetheless, information technology to some extent has noticeably enhanced the transparency of WTO activities and documentation: unlike under GATT, WTO activities are easily accessible through the Web and this encourages better participation by NGOs in the goings-on of the organisation. ${ }^{39}$ The change in the WTO is only in the area of substance and context, while the structure of the

\footnotetext{
${ }^{35}$ See Cottier (2009).

${ }^{36}$ See International Law Association (2006).

${ }^{37}$ See WTO (2006).

${ }^{38}$ For information on WTO coalition building see Wolf (2007).

${ }^{39}$ See Steger (2008).
} 
organisation remains as in the GATT 1947 era. The WTO remains unchanged in the area of modes of daily business by committees and the general council. It is still a member driven organisation, a process of negotiation opposed to a multilateral group and scarcely framed by international agreements. ${ }^{40}$ The WTO is far from a proper legislative process of deliberation and decision making comparable to the process of sovereign law-making. The substantial reform of the dispute settlement system operates without effect and entails the working condition of the political process and at best a new relationship of political and judicial processes. The weakness and handicaps of developing countries' production firms make them very vulnerable in an environment of international competition. The implementation of WTO policies in the developing countries is a continuous problem, demonstrated in the later WTO Doha Rounds ministerial meeting of July, 2008 in Geneva, Switzerland, Bali 3-7 December 2013, Nairobi 2015 and even the $12^{\text {th }}$ Ministerial meeting held in Buenos Aires, Argentina, December $2017 .^{41}$

\section{Agriculture}

In the area of agriculture, enhancement of market access depended on developing countries removing protectionist measures for their own economic growth. This would then generate more income to the farming population in the developed countries, already supported by massive subsidies from their governments. The overwhelmingly agricultural character of most of the less developed countries is a major determinant of the problems they face; especially in the underdeveloped countries of Africa and Asia, where the bulk of the population continues to find its livelihood in agriculture. ${ }^{42}$ Enhancing market access in agriculture is contingent on the reduction of protectionist measures by the developed countries and increasing production in developing nations who are presently dependent on agriculture. ${ }^{43}$

Apart from self-centred political control by some developed countries, the objective of the GATT from its inception was to broker concessions by national governments in the broader interests of free trade ${ }^{44}$ The GATT provided rules reflecting multilateralism and non-discrimination that would enable contracting parties to reap gains from commerce interrelationship in line with principles of comparative advantage. ${ }^{45}$ No doubt, the GATT had been aware that right from 1958 , the domain of agriculture was swayed by protectionist practices such as

\footnotetext{
${ }^{40}$ For some examples of literatures that acknowledge the political functioning of GATT and WTO at Gathi (2006), reviewing Jawara \& Kwa (2004); Wolf (2004).

${ }^{41}$ See WTO (2017).

${ }^{42}$ Ibid.

${ }^{43}$ For example, the agriculture sector, including forestry and fishing, accounts for about 29 percent of India's GDP, and provides direct employment to about 314 million people. Agricultural products formed about 17 percent of India's total merchandise exports in 1996-97. See WTO (1998).

${ }^{44}$ See Aseem \& Hart (2000). .

${ }^{45}$ See Bhagwati (1998).
} 
tariffs and export subsidies. ${ }^{46}$ This was the fundamental point for the international market failure in agriculture as a result of excessive manufacturing leading to dumping in international trade. In preparation for the Uruguay round, the newly formed Cains Group ${ }^{47}$ brought fresh attention to the agricultural sector by focusing on eliminating local production subsidies in developed economies. This included minimising export subsidies and volumes of subsidised exports regulating market access. The Uruguay round led to an Agreement on Agriculture (AOA), a provision that tended to reduce agricultural protectionism through two instruments: the conversion of all import restrictions to tariffs and the guarantees of minimum market access.

This AOA was designed to come into force six years after 1995 and was deferred for a ten year period in the case of developing countries. The implication of the duration was to enable the WTO to modify the subdivisions of agriculture to make tariffs the only system for monitoring market flow. Agriculture has on the whole been exempted from GATT's discipline. ${ }^{48}$ The greatest debacle in the WTO relates to the matters of agriculture, intellectual property rights, general trade in services (GATS) and trade-related investment measures (TRIMS). These matters were not contained in the GATT's earliest provision on trade in goods. There was hardly any support for the inclusion of agriculture in the liberalisation programme, because the United States and major developed countries of Europe were generally captive to strong protectionist lobbies that had constructed elaborate mechanisms of agricultural income support. ${ }^{49}$

The collapse of the Seattle Ministerial conference created a forum to reevaluate the record and remodel what would stand as correct procedure to trade policy and the future of WTO. ${ }^{50}$ The Punta Del Este Declaration called for liberalisation of trade in agriculture and for application of GATT rules and disciplines to export and import measures affecting agricultural trade. ${ }^{51}$ The Dunkel Draft constituted the basis for an agreement that incorporated the major principles set forth at Punta Del Este. The Draft marshalled specific methods of reducing market access barriers, export subsidies and market-perverting internal assistance. With respect to market access, the draft agreement called for a reduction in customs duties including those resulting from ratification by thirty-six percent in the aggregate from 1993 to 1999 , with mandatory minimum reductions of fifteen percent for each tariff line item. The draft noted that all reductions in agricultural tariffs and any expansion of market access would be accomplished in equal instalments. The draft recognised that the developing countries needed special and

\footnotetext{
${ }^{46}$ See Sander \& Inotai (1996).

${ }^{47}$ The Cains Group was formed prior to the Uruguay Round in 1986. This Group argues in favour of agricultural liberalization as they are main exporters of agricultural products. They consist of 17 members mostly from high and middle income with Indonesia as the only low-income country. The Cains Group includes: Canada, Brazil, Chile, Columbia, Argentina, Australia, Costa Rica, Malaysia, Indonesia, New Zealand, Guatemala, Hungary, Paraguay, the Philippines, South Africa, Thailand and Uruguay. See Financial Times (1992).

${ }^{48}$ See GATT (1994b).

${ }^{49}$ See Bhagwati (1998).

${ }^{50}$ See Khor, M. (2000). '

${ }^{51}$ See WTO (2002).
} 
differential treatment relating to market access, domestic assistance and export rivalry. Such policies would be exempt when applied as part of agricultural and rural development programmes.

They included:

- Investment subsidies generally available to agriculture

- Domestic support to producers to encourage diversification from the growing of illicit narcotic crops, and

- Agricultural input subsidies, whether in cash or kind, provided to lowincome or resource poor producers, defined using clear and objective criteria, and which are available to all producers meeting these criteria.

Before the Uruguay round, agricultural exporting countries encountered increasing trade friction, as the industrialised nations increased the level of support they provided to the agricultural sector. Export subsidies, market access barriers, state trading enterprises, health and sanitary regulations, and other measures were used to assist domestic farmers, often at the expense of exploiting countries. ${ }^{52}$ Stewart argued that the Third World agreement in the agricultural area is a prerequisite for a positive overall result in the round. For others, he said that agricultural reform must be tempered by the ability to deal responsibly with an important sector of the economy. Every inch of ground between the differing interests has been identified, measured and evaluated. ${ }^{53}$ The overwhelmingly agricultural character of most of the less developed countries is a major determinant of the problems they face; especially in the underdeveloped countries of Africa and Asia where the bulk of the population continues to find its livelihood in agriculture. ${ }^{54}$ It bears directly on the central question of how interests and ideology influence the present and the future course of protectionism in the world economy. The GATT did not completely purge itself of trade restriction, it is embedded with such protectionist measures as tariffs and subsidies. ${ }^{55}$

The WTO market access negotiation in agricultural policies had been affected by a good number of deadlocks. For example, the round of trade negotiations was launched in Doha, Qatar in November 2001 in a bid to arrange the next decade of free trade. The Doha round came two years after efforts to launch a round of negotiations in Seattle collapsed amid mass protests. ${ }^{56}$ By the same token, the Doha round of world trade talks of September 2003 in Cancun, Mexico, ended in disarray after rich and poor nations failed to bridge deep divisions over agriculture and investment rules. ${ }^{57}$ The clash in Cancun came after a Group of 20 (G20) important developing countries, including Brazil, China, India and South Africa mounted an extraordinary challenge to the United States, the EU and Japan. ${ }^{58}$

\footnotetext{
${ }^{52}$ See Stewart (1992).

${ }^{53}$ Ibid.

${ }^{54}$ Ibid.

${ }^{55}$ See Bhagwati (1987).

${ }^{56}$ See Sage (2004).

${ }^{57}$ Ibid.

${ }^{58}$ Ibid.
} 
Third World leaders said that Western agricultural policies drove their farmers out of business, exacerbating poverty and famine. ${ }^{59}$ Sage argues that the Western authorities' refusal to yield to negotiations faded hopes for a global trade agreement, which according to the World Bank estimates would lift 140 million people out of poverty by $2015 .^{60}$ The deadlock incident of the September 2003 Cancun Ministerial Conference paved the way for WTO members to convene in Geneva in 2004. They began to make attempts to organise the negotiations by putting the entire action plan back on track. In the final hours of the long and drawn out meeting in Geneva in 2004, negotiators representing 147 WTO countries tried to end years of deadlock by reaching a consensus that would empower discussions focused on eliminating trade barriers. In the meeting, a group of countries referred to as 'Five Interested Parties' (FIP) was chosen, meant to resolve the earlier deadlocks. This group consisted of important political and economic technocrats in world trade; the United States, EC, Australia, Brazil and India. The entire world's poor countries were represented by only two nations. The WTO's agriculture propositions concentrated on three pillars; boosting export subsidies and the elements of other export support that might distort trade; driving down tariffs to increase market access; and reducing domestic support in some areas. $^{61}$

Supachai Panitchapkdi, the then WTO Director General, described the WTO July 2004 Package ${ }^{62}$ on agricultural reform, which put farm subsidies at the top of the agenda as 'a triumph'. Robert Zoellick, the U.S. Trade Representative, said it was 'historic,' while Brazil hailed it as 'the end of subsidies'. ${ }^{6}$ Accordingly, Celine Charveriat of Oxfam said:

"negotiations may trumpet breakthroughs on export subsidies and cotton, but there are no cast-iron commitments here and no clear timeline for reform. We need a far more ambitious and radical approach. If rich countries do not immediately put their promises into action, this declaration will become just one more stage in a long journey of disappointment and deception". 64

The WTO July package report unleashed reaction and criticism from many quarters who suggested that it was guilty of disproportionate handling of implementation matters. Such reactions came from the developing countries that were not happy with the package proposed by the US-EU. As a result, a coalition was formed by the developing countries led by Brazil, India and China (BRICs), as the G20 on agriculture to match against the USA and EU. ${ }^{65}$ Oxfam argues that a little success has been realised by the developing countries in the form of stronger language to agricultural export subsidies and export credits and success in

\footnotetext{
${ }^{59}$ See Jawara \& Kwa (2003).

${ }^{60}$ See Sage (2004).

${ }^{61}$ See Mortished (2004).

${ }^{62}$ See WTO (2004a) and WTO (2005).

${ }^{63}$ See Mortished (2004).

${ }^{64}$ See Charveriat (2004).

${ }^{65}$ See Clapp (2006).
} 
negating three out of four 'Singapore Issues', 66 as negotiations were launched on trade facilitation. However, the final text remained disappointing and did not do much to improve the round of negotiations. Economists estimated subsequent deals to cost beyond $\$ 500$ billion per annum to the volume of global economy. Moreover, some trade negotiators and development groups criticised the draft on grounds that it benefits the West and requires much work to attain a deal in favour of the poor nations. ${ }^{67}$

In line with this critique, some non-governmental organisations (NGOs) and developing nations had doubts about the western countries' preferred commitments because their promises were not fulfilled in the past. ${ }^{68}$ Contributing, Celine Charveriat of Oxfam International Geneva said in the July 30, 2007 draft.

"After days of closed door negotiations, rich countries have delivered a deeply unbalanced text as a take or leave it option. This puts developing countries in the unfair position of having to accept a bad deal or reject and get blamed by the U.S. and EU for failure". ${ }^{69}$

Ideally, the developed countries could cut their subsidies with no compromise to reciprocate by allowing their manufactured goods influx which would enable them to retain an unfair competitive position. Walden Bello, a critic, presented a simple description of July 2004's supporting structure:

The developing countries have waited nearly 10 years for the trade superpowers that dominate the WTO to show sensitivity to their efforts to change global trade from being an instrument of their domination to serving as a mechanism to advance their economic development. For this patience, they have been rewarded with a succession of anti- development negotiating frameworks and texts culminating in the July framework. ${ }^{70}$

The developed countries appear to have ignored consideration of such objects which militated against the progress in the WTO rounds. For instance, 'the Common Agriculture Policy' (CAP) process of reform which produced a moderate package by June 2003 and the reverse description by the U.S Farm Act decreed after the Doha Ministerial conference. ${ }^{71}$ In line with the above, Action Aid commented on EU and United States 'bullying and arm-twisting tactics'. ${ }^{72}$ This means that whenever developing countries engage in hard bargaining against western preferences, as occurred prior to Doha, a number of tactics are adopted to discourage them. These usually come in the form of combinations of inducements to pertinent countries or their governments deeming them 'unfriendly blacklisted

\footnotetext{
${ }^{66}$ Trade facilitation, trade and investment, trade and competition policy and transparency in government procurement.

${ }^{67}$ See Elliot (2004).

${ }^{68}$ See Goh, Hormeku \& Khor (2004).

${ }^{69}$ Charveriat (2004).

${ }^{70}$ See Bello (2004).

${ }^{71}$ Charveriat (2004).

${ }^{72}$ See Kanaga (2004).
} 
nations.' The suggestion is that their preferential trade agreement must be suspended, employing mounting pressure on capitals that usually go with blocking information or threatening to discontinue the jobs of the countries' representatives as well as those of their Ambassadors. ${ }^{73}$ Moreover, they may indulge in the deployment of middle-income economies to convince low income economies to reconsider their stance. ${ }^{74}$ Arguably, the EU/U.S. 'arm-twisting and bullying relationship' could be likened to an effort to move the developing countries backward into the period of colonial economic interdependence. This was designed to invoke the economic dependence theory that existed during the colonial period that left the colonial masters dictate the pace of every government policy. The problem here seems to be about power sharing between the North/ South and 'power' remains a contestable nomenclature. There is a level of difficulty in ascertaining how power works. It is 'puzzling given that the dispute over the function of capabilities and other facets of power enjoys a long and distinguished tradition in the history of international relations theory'. ${ }^{75}$ In international politics, realist and neo-realist scholars are inclined to hard or coercive power that 'compel another to do something it does not want to do' ${ }^{76}$ The liberal school builds on the understanding of power in an international cooperation angle that rejects the neo-realists' claim that relative gains are the motivating factor behind cooperation. ${ }^{77}$ In power negotiations, the liberals take into consideration that it is between sovereign unequal states and preferences are to be born in mind while bargaining. Apparently the weaker developing states that are in need of certain agreements often give in and carry minimal influence in negotiations. ${ }^{78}$ The interaction in the display of power in WTO negotiations has led to asymmetrical outcomes. The rationalisation of power goes beyond typical "resource perspective" to how these powers was structurally accepted by member states in deliberative manner. ${ }^{79}$ Power in the WTO is focused on the dispute settlement system. It is a concept that is often defined in opposition to law in International Economic Law literature. Ordinarily, it is associated with politics, whilst law is visualised as non-political.

In contemporary WTO negotiations, the DCs, in a bid to minimise their structural positions join resources with other participating nations through coordination with NGOs such as Third World Network and Oxfam. One way in which developing countries pool their resources together is through coalition building. ${ }^{80}$ The focal points in the DDA were special and differential treatment issues, textiles and clothing, agriculture, industrial and manufactured goods, services and development. ${ }^{81}$ The Doha conference in 2001 set the agenda whereas the Cancun ministerial conference of 2003 was to amplify the aim and to achieve

\footnotetext{
${ }^{73}$ See Jawara \& Kwa at 275-6.

${ }^{74}$ Ibid.

${ }^{75}$ See Schneider (2005) at 667.

${ }^{76}$ See Barnett \& Duvall (2005) at 40.

${ }^{77}$ See Powell (1991).

${ }^{78}$ See Schneider (2005). For a general overview of 'Power' see Guzzini (2005).

${ }^{79}$ See Lake (2004).

${ }^{80}$ See Amrita (2003).

${ }^{81}$ See Doha Ministerial Declaration (2001).
} 
the boost the negotiation deserved. Instead, the ministerial collapsed amidst disagreements. Additionally, the US-EU joint proposal on agriculture was blocked and the G20 (Cains group) under the leadership of Brazil, India and South Africa lobbied against three of the four Singapore issues being included in the negotiating table. ${ }^{82}$ Nonetheless, the July package was agreed upon, yet overall negotiation procedures remained virtually the same, with no change in negotiation context until July 2006. The agreement on a date for phasing out export subsidies coupled with the proclamation of an 'aid for trade' package was the only tangible outcome to demonstrate to the developing countries that these rounds were actually for development issues. The power interaction in the WTO negotiations which are characterised by law-based bargaining has witnessed under current negotiations power-based bargaining. ${ }^{83}$ WTO DDA negotiations of $9^{\text {th }}$ Ministerial meeting held in Bali 3-7 December 2013 settled on deals with limited relevance to global trade and such deals reached are of greater importance to Industrialised nations as against their counterparts in DCs/LDCs. ${ }^{84}$ Recently, the traditional global economic governance is challenged by the new rising powers called the BRICs' such as China, India and Brazil. Coincidentally, these rising powers have taken veritable pathways to power. Whilst Brazil and India created and spearheaded the organisation of developing countries coalitions, which has kept them at the limelight in the WTO negotiations, China's rise to power is associated with its sporadic economic growth. ${ }^{85}$ The global economic order has been dominated by the US power and the US has led in the leadership of globalisation and neoliberalism. The trajectory of the rising powers of the BRICs' in global economic governance could affect the global economic dominance of the US. This has been exemplified in the recent successful WTO trade disputes brought by Brazil against US and EU which has given the developing countries (G20), a paramount attention in Doha Rounds trade policies. ${ }^{86}$ The Brazil's leadership position in the developing countries Coalition and activism in the WTO meetings has received praise from many quarters. Brazil has become the main protagonists of free trade agenda and advocated for liberalisation of global markets. It could be argued that Brazil's wide advocate of global free market is motivated by its growing export oriented agribusiness sector. This on the other hand could be a strong weapon driven by Brazil against the developed nations and MNCs who have used the WTO neoliberal agenda to milk the DCs/LDCs ailing economy. Nonetheless, Brazil's interest could be informed by development and economic equality strategized to balance the over orchestrated politics of global economic imbalance. By and large, the WTO December 2015 Nairobi Ministerial Conference

\footnotetext{
${ }^{82}$ The Singapore Issues are competition, Investment, Public Procurement and Trade Facilitation.

${ }^{83}$ In the context of GATT/WTO bargaining, Steinberg has defined law -based bargaining as where "States take procedural rules seriously, attempting to build a consensus that is pareto- improving, yielding market-opening contracts that are roughly symmetrical". Whereas in power-based bargaining, "states bring to bear instruments of power that are extrinsic to rules(instruments based primarily on market size), invisibly weighting the decision-making process and generating outcomes that are asymmetrical and may not be pareto - improving". See Steinberg (2002) at 341.

${ }^{84}$ See Wilkinson, Erin \& Scott. (2014).

${ }^{85}$ Hopewell (2015).

${ }^{86}$ Veiga (2005). See also Hopewell (2013).
} 
agreed on a new negotiating mode whereby participation and consensus were brought into WTO trade talks to serve as a way of ensuring trade benefits for DCs and LDCs. However, the trade deals agreed in the Nairobi Ministerial Conference is in tandem with asymmetrical trade deals leaning in favour of developed countries against DCs and LDCs. Although the Nairobi Ministerial Conference has reshaped the future of WTO trade deals to enable trade gains for DCs /LDCs, but the implementation of the Nairobi Ministerial Conference deals to DCs/ LDCs may be a different approach as before. ${ }^{87}$.

The reduction of Industrialised Countries trade distorting domestic support is very important to enable DCs get access to not only Industrialised Countries market, likewise to DCs markets. West African Cotton-producing countries suffered extreme poverty because of trade distorting domestic support in the developed Countries. ${ }^{88}$ The WTO should implement uniform agriculture policies to all countries and ensure exemptions for low-income countries available investments and import subsidies. The WTO end date agreements of 2013 on parallel elimination of all forms of exemption subsidies should be taking advantage of by the DCs on firmer negotiations in International food aid, exports trading, export financing support. If the impasse on the reform of agriculture continues, the DCs should change their negotiation strategies in the Doha Round or ask for free tariffs like United Kingdom in the BREXIT trade deals with the European Union (EU). ${ }^{89}$ The DCs will not be blamed for asking for Special and Differential treatment or reduction of tariffs equating the same level of agriculture subsidies provided for the Industrialised Countries. ${ }^{90}$ The DCs should not accept anything lower than the level of tariff reduction accorded to the Industrialised countries. They should not lower their guards and should continue indefinitely asking for reduction commitment on the freight subsidies and marketing costs on export shipments. ${ }^{91}$ The DCs must maintain common front insisting on the same level of domestic support of the Industrialised Countries in order to end the present agricultural trade distortions. ${ }^{92}$ They should be bold and courageous in WTO negotiations to achieve a world agricultural reform. It will be legitimate if DCs/LDCs take advantage of GATT Article XXIV to negotiate for zero tariffs and zero quota in imports and exports in order to achieve balanced global economic development. ${ }^{93}$

\section{Decision making}

In the past, the US, the EU and the Quad were the main decision-makers in the WTO, but new market capacities and new alliances have led to a change in the decision-making process. Thus the emergence of the recent proliferation of

\footnotetext{
${ }^{87}$ Wilkinson, Erin \& Scott (2016).

${ }^{88}$ Igwe (2011).

${ }^{89}$ See Leroux (2017).

${ }^{90}$ See Irwin (2007

${ }^{91}$ Hoda \& Gulati (2008).

${ }^{92}$ See Wood (2019).

${ }^{93}$ See Morris (2019).
} 
coalition building ${ }^{94}$ and informal meetings of small groups changed the decisionmaking process 95 . The new negotiation process has changed from July 2004's package; the inner circle are the G6, then the creation of the "Green Room" lastly the head of delegations (trade negotiation committees). The need to reach consensus on issues of agriculture and non-agricultural market access (NAMA), prompted the creation of the G6 ${ }^{97}$ Thus the G6 has become the current inner circle of decision-making of the WTO. The G6 is not an official WTO institution. The meetings have no clear administrative procedure to determine who calls or presides over the meetings, neither does it take minutes. Although the Director General of the WTO could be invited to the meeting, it is not mandatory. In the meetings, the US represent their positions, other participating countries represent themselves or speak on behalf of a coalition: Australia represents the Cains group, Japan the G10, India the G20 and G33, and Brazil the G20. ${ }^{98}$ Apart from the G6 or FIPs position as inner-circle decision-makers in WTO, other groups are the 'green room' which are like 'FIPs extended' or the so-called S-12 process. ${ }^{99}$ This forum meets either at ministerial or ambassadorial level and committed to a general level or specific matters commonly known as "Room-F-Meetings". This arrangement had been criticised even in Seattle for lacking transparency and segregative. The incidence of Seattle led to intense meetings to create a 'code of conduct' to deal with issues of effective participation and internal transparency which has not been settled. Hitherto, representations in the 'green room' were made by the advanced economies, representatives of coalitions and a few medium sized developed countries. On the other hand, the third group in decision making is made up of groups that are open to all the parties such as the trade negotiation committee and heads of delegations. These groups are so large that they cannot attain the practical negotiation stage. They organise proposals and clarify issues but they cannot engage successfully in complex or contentious issues which ordinarily move to the general membership; whereas negotiations decided on the power economies' level are hardly reversible, with few exceptions. ${ }^{100}$

The incidence can lead to limited contributions by individual members and lack of cohesion between the members. Parties need to be aligned, homogenous and focused on specific interests. Structural power through the evolution of the

\footnotetext{
${ }^{94}$ See Wolf (2006).

${ }^{95}$ See Croome (1995).

${ }^{96}$ Green Room means a representation of up to 30 WTO member countries invited by the WTO Director General to form a consensus on critical issues of negotiation brought to the WTO as an institution.

${ }^{97}$ The July package agreement was virtually negotiated between the FIPs (Five interested parties: US, EU, Brazil, India, Australia), plus Japan which made up the G6

${ }^{98} \mathrm{G} 10$ group are net importers of agricultural products who defend high levels of domestic support and market access protection for a number of products. Key members include the Republic of Korea, Japan, Norway and Switzerland. The G33 are a group of developing countries asking for differential treatment related to food security, sustainable livelihoods and rural development needs

${ }^{99}$ G6 and Norway, Canada, China, Malaysia, Kenya, and Egypt that share information which concerns agricultural subsidies.

${ }^{100}$ Such exceptions are like India's success in Doha ministerial conference to obtain clarification on a decision-making issue in connection with the Singapore Issues and Norways credible argument that granted it chance to introduce a sentence into the July package at a late stage.
} 
WTO into the DDA is the critical element that determines the negotiating position of contracting parties. The negotiating positions are based on market capacities and 'sense of balance' in order to qualify to be invited into the negotiating table. ${ }^{101}$ The presence of this kind of forum increasingly results in developing countries adopting a defensive approach to negotiation as they have come to terms with occupying a weak negotiating position in the WTO. Nonetheless, to counter the structural power of the advanced countries in the DDA the building of coalitions between DCs and middle sized developed economies becomes essential. Engaging in coalition building enables contracting parties to improve their bargaining position through alliance building; gain diplomatic clout, acquire expertise through knowledge and resource sharing or simply use coalitions to close the information gap. If they succeeded in doing so, it might strengthen their negotiating power and create better chances of success in achieving their agendas in WTO negotiations. This alliance requires the creation of regional networks: African, East Asian, Eastern and Central European, South American and South Asian networks. ${ }^{102}$ Coalitions like in the case of the BRICs can help the DCs strengthen their collective bargaining position, influence negotiation outcomes, and promote effective and democratic decision making in the WTO. To form a successful alliance, the parties require distinctive goals, willingness and readiness of common purpose, and an understanding of one another. Low-income DCs use International Government Organisations (IGOs) such as South Centre, the Commonwealth Secretariat, or NGOs like Oxfam, Third World Network, and Action Aid to support them in negotiations. Generally, countries use coalitions in different ways. For example, a country such as Brazil uses coalition as a matter of having a large constituency to get diplomatic weight, but weaker developing countries enter coalition as a way to exchange information and enhance their level of technical/ legal knowledge. While other DCs use coalitions to put across their message more forcefully, the US and the EU can use, but do not really depend on coalitions as they follow the normal GATT/WTO system. In order to increase political clout, some developing countries may enter into coalitions with a developed country. Coalitions based on political grounds often lack flexibility, homogeneity and the acceptance needed by other parties to engage in negotiations. This arrangement can easily lead to bilateral arm - twisting. ${ }^{103}$ Strong coalitions must have uninterrupted systems of information exchange, smooth debriefing, a quasilegitimised representation, high participating numbers and a proven level of trust. There have been divergent views between African groups on several issues in the DDA except on issues of cotton and trade facilitation. The question is why have the 'development needs' of the DCs failed to be addressed by the WTO? It is argued that the African coalitions and/or DCs are mainly engaged in blocking tactics rather than effectively shaping the WTO agenda. Academic literature on GATT has characterised the role of the DCs in the GATT as potentially defensive and unprepared to make tariff concessions but more interested in getting special

\footnotetext{
${ }^{101}$ Australia did not qualify to be in the negotiation in Doha for its market access but for its sense of balance as the chair of the cains group to participate.

${ }^{102}$ See Rolland (2007) at 524.

${ }^{103}$ See Amrita (2004) at 424.
} 
and differential treatment concessions. ${ }^{104}$ This is far from accurate of the ITO and GATT evolution because the DCs have played a notably active role in shaping the agenda of the GATT/WTO. ${ }^{105}$ A conventional academic literature approach is that the WTO has not been able to aid the DCs on three points: (a) that the DCs have played a passive and defensive role in the GATT, (b) that the DCs lack participation in the exchange of concessions and (c) that the DCs have unusually focused on the implementation of special and differential treatment in the GATT. ${ }^{106}$ This perspective of reasoning has clouded the understanding of many but is far from the truth. The role of the developing countries in the GATT is neither passive nor defensive, as was emphasised by Michael Finger when he stated that 'through GATT's Tokyo Round that ended in 1978, DCs participation in multilateral trade negotiations was either passive or defensive. Developing countries that had joined the GATT had in large part remained bystanders; many had acceded under Article XXXVI-r(c), which exempted them from having to negotiate concessions in order to enter ${ }^{107}$. Along this line of argument, other academic writers recognize that the Uruguay Round Agreement was not balanced and that 'developing countries had given more than they got - a concern that the basic GATT/WTO ethic of reciprocity had been violated' The result of this was 'lack of assessment of the impacts of the agreement [...]' and that the agreements were 'poorly understood and certainly not quantified' ${ }^{108}$ On the other hand, some DCs' writers have taken a gloomy perspective by saying that the developing countries' majority membership in the GATT/WTO did not help them; rather, it was a weakness. ${ }^{109}$ It has also been argued that the DCs in negotiations do choose to remain silent because of their lack of knowledge on the issues or because they feel intimidated by the reactions of the developed nations and their opposition have been described as 'stiff resistance and sudden collapse'. ${ }^{110}$ The point is that the DCs lack the technical facilities and organisational negotiating capacity to succeed in multilateral bargains but it does not necessarily mean that they were passive participants in the GATT. This was clearly shown in the active role played by the DCs in formulating formidable coalitions for their development interests that echoed in the beginning of the Doha Round. Nonetheless, the Uruguayan case against 15 OECD members of the GATT in 1961 clearly demonstrated the active participation of the DCs in the GATT. ${ }^{111}$ The second reason that prevented GATT addressing DCs' development needs is highlighted above as a lack of participation in the exchange of concessions. Under this premise, Will Martin and Patrick Messerlin asserted that:

"the fact that developing countries were not actively participating in the Kennedy and Tokyo Rounds made it much easier for the Industrialised Countries to create

\footnotetext{
${ }^{104}$ See Faizel (2008).

${ }^{105}$ See Faizel I. (2007).

${ }^{106}$ See Ismail (2008).

${ }^{107}$ See Finger (2007)

${ }^{108}$ See Ostry (2002).

${ }^{109}$ See Bhagirath (2003).

${ }^{110}$ See Jawara \& Kwa (2003).

${ }^{111}$ See Wilkinson \& Scott (2008).
} 
mechanisms such as the multi-fibre agreement (MFA) targeted against exports from developing countries, to exclude other labour-intensive products from full formulabased liberalisation, and to offer tariff preferences only at the discretion of the importer.' ${ }^{112}$

This is a misleading assertion since from the early rounds of the GATT, the US and the EC maintained that the DCs be excluded from participation on the principal supplier rule, internal taxes and quotas which invariably excluded negotiations on tropical products and reciprocity. ${ }^{113}$ The third point focused on Special and Differential Treatment, Martin and Messerlin stated that:

"prior to the Uruguay Round, most DCs had sought to achieve their objectives primarily through Special and Differential Treatment provisions. This was partly as a result of the power of the interest groups in import substituting firms in developing countries' and that 'many of these countries resisted the use of key GATT approaches, such as reciprocal liberalisation and the principle of nondiscrimination. $" 114$

However, these writers have failed to recognise the concept of MFN- Article 1 of GATT $1947^{115}$ and Reciprocity argued by the DCs for the conditions of development and interests of DCs to be taken into consideration. ${ }^{116}$ Moreover, Part IV of the GATT (1965) and the 1979 Enabling clause formed the background for the Special and Differential Treatment rules of the Tokyo Round which were partially informed by the developed nations' neglect of the special needs of DCs shown by protectionist measures against the latter's exports, mostly of agriculture and textiles. History shows that the DCs participated adequately in the GATT from its inception; of its 23 original members, 10 were DCs. ${ }^{117}$ In 1960, GATT had 37 contracting parties, of which 21 were developed nations and 16 were DCs. In 1970, GATT had 77 contracting parties, of which 27 were developed nations and 52 were DCs. In 1987, GATT had 95 contracting parties, of which 29 were developed nations while 66 were DCs. The participation of DCs took a progressive turn as 25 DCs participated in Kennedy Round, 68 in the Tokyo Round, 76 in Uruguay Round while 107 members were representatives of DCs out of the 153 members of the WTO. ${ }^{118}$ It has to be appreciated that as at the beginning of the GATT, the majority of the DCs were still under colonial rule or newly independent and in most cases still under the influence of their colonisers or

\footnotetext{
${ }^{112}$ See Martin \& Messerlin (2007).

${ }^{113}$ See Wilkinson \& Scott (2008).

${ }^{114}$ See Martin \& Messerlin (2007).

${ }^{115}$ Provides that: "any advantage, favour, privilege or immunity granted by any contracting party to any product originating in or destined for any other country shall be accorded immediately and unconditionally to the like product originating in or destined for the territories of all other contracting parties." This provision prohibits members from discriminating on products based on source. Joseph Stiglitz described this provision as ineffective and characterised WTO rules as unbalanced, unfair or prejudicial to the development needs of the DCs. See Stiglitz (2000).

${ }^{116}$ See Bagwell, Staiger \& Yurukoglu (2020).

${ }^{117}$ See Hudec (1987).

${ }^{118}$ See WTO (2001c).
} 
represented by them, as in the case of Southern Rhodesia (Zimbabwe) and South Africa. Moreover, the framework of the GATT was structured in such a way that it was an 'exclusive club' of westerners with minimal interest in the non-western world. ${ }^{119}$ The developing countries were vehemently opposed to the inclusion of services, intellectual property and investment in the GATT and opted for a round that would address industrial products and agriculture. ${ }^{120}$

It is admitted that the developing countries are divided on many issues in the negotiations ranging from Singapore, preference erosion, the use of food aid, the role of Dispute Settlement Body (DSB) and South - South trade. The developing countries have huge reservations about the design of the WTO structure and decision-making in the negotiating committees. Jonas Tallberg has examined this development, stressing the capture of the more important committees lies in the monopolisation of the chair by advanced countries. It is evident that trade negotiations from Kennedy Round in 1960s to Doha Round in 2001 reflected the overpowering influence of the advanced countries through the chair. ${ }^{121}$ These rounds have witnessed the brokerage services of the supranational chairman of the Trade Negotiation Committee (TNC). The committee chairman is the director general of the WTO secretariat who plays the role of a central coordinating body of the international trade rounds with the power to 'function as package-deal engineer' and who is responsible for 'Stitching together the package agreements that can secure unanimous adoption by the parties' ${ }^{122}$ The multilateral problem of bargaining further ranges from communicating preferences to exchanging information with large members of the organisation. ${ }^{123}$ Nonetheless, Hampson with Hart observed that:

"The chief obstacles to multilateral negotiations are complexity and uncertainty: complexity created by the large number of parties to the negotiation and issues on the table, uncertainty heightened by the difficulties of communicating preferences and exchanging information among a large number of participants". 224

The system is skewed against developing countries for the protection of the whims of the powerful nations. This situation does not portray the pursuit of common trade policy agenda that would increase growth in the individual countries. The term 'development round' has not helped the developing countries' bargaining power as the notion of 'development' has not been reflected in the rounds: rather it unfolds into contestations. A development oriented round must be based on reciprocity without the logic of conflicts that is deeply embedded in trade negotiations. Whereas, the interpretative framework of the 'development' paradigm should stand as a tower of strength to developing countries' coalitions, such as the G20, G33 and G90.

\footnotetext{
${ }^{119}$ See Hudec (1990).

${ }^{120}$ See Croome (1999).

${ }^{121}$ For Kennedy Round, see Preeg (1970); For Tokyo Round, see Winham (1986); For Uruguay Round, see Sjostedt (1986); For Doha Round, see Odell (2005).

${ }^{122}$ See Tallberg (2006).

${ }^{123}$ See Zartman (1994).

${ }^{124}$ See Hampson \& Hart (1994) at 23.
} 


\section{Conclusion}

It is argued in this writing that the intent of the WTO as an institution is to liberalise international trade, but the question remains to whose advantage? The WTO as an institution is challenged by possible contradictions between its neoliberal ideology of trade liberalisation or deregulation and its awakening to the realisation that its market policies will be based on strict impartial implementation of trade regulation, keeping in mind its laudable provisions especially as it affects the developing countries ${ }^{125}$ This writing has demonstrated grave inequality in WTO implementation policies towards the DCs/LDCs especially as it relates to agriculture which gives the DCs/LDCs comparative advantage over the Industrialised Countries. The WTO restrictive trade system in agriculture should be reformed to ensure sustainable development in the DCs/LDCs and to combat market distortions which breeds global economic imbalance. The WTO global trade liberalisation development approach should be based on objective conjecture of just and equitable global income distribution. This can be achieved through the axiom of 'non-discrimination', 'reciprocity' provided in the GATT agreement, and crystallised in the WTO agreement.

\section{References}

Amrita, N. (2003). International Trade and Developing Countries: Coalitions in the GATT and WTO. London: Routledge.

Amrita, N. (2004). "The Ministerial Process and Power Dynamics in the WTO: Understanding Failure from Seattle to Cancun", New Political Economy 9(3): 413428

Aseem, P. \& J.A. Hart (eds.) (2000). Coping With Globalisation, London: Routledge. At https://www.wto.org/english/res_e/booksp_e/casestudies_e/case7_e.htm

Bagwell, K., Staiger, R.W. \& A. Yurukoglu. (2020). "Multilateral Trade Bargaining: A First Look at the GATT Bargaining Records" in American Economic Journal: Applied Economics, 12(3):72-105.

Barnett, M. \& R. Duvall. (2005). "Power in International Politics" in International Organisation 59(1):39-75.

Barton, J., Goldstein, J., Josling, T. \& R. Steinberg (2006). The Evolution of the Trade Regime: Politics, Law, and the Economics of the GATT and the WTO. Princeton: Princeton University Press.

BBC (2009). World Trade talks end in collapse. BBC News and Current Affairs (29 July).

Beattie, A. (2008). 'Hangovers but no anger on the morning after' Financial Times (31st July).

Bello, W. (2004). 'D-Day for the WTO' in Focus on the Global South, July 28.

Bello, W., Cunningham, S. \& B. Rau (1994). Dark Victory: The United States, Structural Adjustment and Global Poverty. New Edition. London: Pluto Press.

Bergsten, C.F. (1998). 'Fifty Years of the GATT/WTO: Lessons from the Past for Strategies for the Future', paper presented at the symposium on the world trading system 'Fifty Years: Looking Back, Looking Forward'. Geneva: World Trade Organization and Graduate Insitute of International Studies.

\footnotetext{
${ }^{125}$ See Bhagwati \& Hudec (1996).
} 
Vol. 7, No. 1 Igwe: WTO, A Multilateral Trade Institution or a Parallel Organisation...

Bhagirath, L.D. (1998). Deficiencies, Imbalances and Required Changes. London: Zed Books.

Bhagirath, L.D. (2003). The WTO and the Multilateral Trading System: Past, Present and Future. London: Third World Networs. Zed Books.

Bhagwati, J. \& R.E. Hudec. (1996). Fair Trade and Harmonisation Prerequisites for Free Trade? Cambridge, MA:MIT press.

Bhagwati, J. (1987). World Development Report', 1987 Barriers to Adjustment and Growth in the World Economy. Industrialization and foreign Trade, World Bank Indicators. Published for World Bank, Oxford University Press.

Bhagwati, J. (1998). Protectionism. Cambridge, Massachusetts: The MIT Press.

Buffie, E. F. (2001). Trade Policy in Developing Countries. Cambridge: Cambridge University Press.Charveriat, C. (2004). "'Arrested Development", Trade Talks Moves Inches but Miles Remain. At https://www.oxfam.org.nz/news-media/mediareleases/arrested-development-trade-talks-move-inches-but-miles-remain/

Clapp, J. 2006). 'WTO Agriculture Negotiations: implications for the Global South" in Third World Quarterly 27(4):563-577.

Cottier, T. (2009). ' A Two-Tier Approach to WTO Decision Making. "NCCR Trade Working Paper No 2009/06, March.

Croome, J. (1996). "Reshaping the World Trading System: A History of the Uruguay Round, Geneva: WTO News: Press Release, January 16.

Croome, C. (1999). Reshaping the World Trading System: A History of the Uruguay Round, $2^{\text {nd }}$ edition. Boston: Kluwer Law International.

Deardoff, A. (2007). 'Trade Policy Options for Developing Countries Outside the Doha Round. University of Michigan, Prepared for ARTNet Research Workshop on Emerging Trade Issues for developing Countries in Asia-Pacific Region, December 11. http://www.unescap.org/tid/projects/tradeissue_deardoff.pdf

Doha Ministerial Declaration: WT/MIN(01)/DEC/1 20 November, 2001.

Elliot, L. (2004). 'Deal on Global Trade Holds Out Hope For Poor Nations', The Guardian of 2 August.

FAO (2000). Food and Agricultural organisation (FAO), 'Agricultural, Trade and Food Security: Issues and Options in the WTO Negotiations from the perspective of Developing Countries, Vol.II: Country case studies', Rome: Food and Agriculture Organisation.

Fergusson, P. S, \& Ian F. (2008). 'Congressional Research services 26 July.

Financial Times (1992). 'Australia Backs GATT Compromise Package’, 8 January, 3.

Finger, M. J. (2007). 'Implementation and imbalance dealing with hangover from Uruguay Round' in Oxford Review of Economic Policy 23(3):440-460.

Gathi, T. (2006). 'The High stakes of WTO Reform: Behind the scene at the WTO: The Real World of Trade Negotiations' in Michigan Law Review 104:1361-1386.

GATT (1947). General Agreement on Tariffs and Trade: Marrakesh Agreement Establishing the World Trade Organisation

GATT (1994b). General Agreement on Tariffs and Trade 1994, Apr. 15, 1994, Marrakesh Agreement Establishing the World Trade Organisation. Annex 1 A, The Legal Texts: The Uruguay Round of Multilateral Trade Negotiations 17 (1999), 1867 U.N.T.S. 187, 33 I.L.M 1153 (1994) GATT Agreement, - Articles X1 and XV1WTO (1994).

Gibbs, M. (1998). 'Special and Differential Treatment in the Context of Globalization', note presented to the G15 Symposium on Special and Differential Treatment in the WTO Agreements, New Delhi: UNCTAD.

Goh, C.Y., Hormeku, T. \& M. Khor (2004). 'Critical Comments on Revised Text by Developing Countries', Third World Network, July 30 
Guzzini, S. (2005). 'The Concept of Power: a Constructivist Analysis' in Millennium 33(3): 4951-521.

Hampson, F. O. \& M. Hart (1994). Multilateral Negotiations. Lessons from Arms control, Trade, and Environment. Baltimore: The Johns Hopkins University Press.

Hoda, A. \& A. Gulati, (2008). WTO Negotiations on Agriculture and Developing Countries. Published for the International Food Policy Research Institute (IFPRI). Baltimore, MD: Johns Hopkins University Press. https://books.google.co.uk/book s/about/WTO_Negotiations_on_Agriculture_and_Deve.html?id=PPxGAwAAQBAJ $\&$ printsec $=$ frontcover\&source $=\mathrm{kp} \_$read_button\&redir_esc $=\mathrm{y} \# \mathrm{v}=$ onepage $\& \mathrm{q} \& \mathrm{f}=\mathrm{false}$

Hopewell, K. (2013). "New Protagonists in Global Economic Governance: Brazilian Agribusiness at the WTO" in New Political Economy 18(4):603-623.

Hopewell, K. (2015). "Different Paths to power; The rise of Brazil, India and China at the World Trade Organisation" in Review of International Political Economy 22(2):311338. https://www.tandfonline.com/doi/abs/10.1080/09692290.2014.927387.

Hudec, R.E. (1990). The GATT Legal System and World Trade Diplomacy, $2^{\text {nd }}$ ed. Salem (N.H.): Butterwoth Legal Publishers.

Hudec, R. E. (1999). 'The New WTO Dispute Settlement Procedure: An Overview of the First Three Years' in Minnesota Journal on Global Trade 8:1-53.

Hudec, R.E. (2010). Developing Countries in the GATT legal System: with a Foreword by J. M. Finger. Cambridge University Press.

Igwe, I.O.C. (2011). 'The International Trade Law Context of Textile \& Clothing: Old Constraints and New Challenges". BIU Law Journals, 11(1):146-185.

Igwe, I.O.C. (2019). "Recognising the Various Trends of Globalisation: Inequality in International Economic Relations" in Athens Journal of Law 5(1):1-22

International Law Association, (2006). Toronto Conference, International Trade Law, Seventh Report of the Committee, paragraph 38(b). http://www.ila-hq.org/down load.cfm/docid/B8DE706-B7A2-4BA3-92F38D46C61FA203

Irwin, D.A. (2007). "GATT Turns 60" in Wall Street Journal of 9 April. https://www. wsj.com/articles/SB117607482355263550

Ismail, F. (2007). Mainstreaming Development in the WTO: Developing Countries in the Doha Round. CUTS International and Friedrich Ebert Stiftung

Ismail, F. (2008). 'Rediscovering the Role of Developing Countries in GATT before the Doha Round' in The Law and Development Review, De Gruyter 1(1):51-73.

Jawara, F. \& A. Kwa (2004). Behind the Scenes at the WTO. The real World of Trade Negotiations - The Lessons of Cancun. London: Zed Books.

Kanaga, R. (2004). 'Divide and Rule: The EU and U.S. Response to Developing Countries Alliances at the WTO' in Third World Network/

Khansari, A.M. (1996). 'Searching for the Perfect Solution: International Dispute Resolution and the New World Trade Organization' in Hastings International and Comparative Law Review, 20:183-203.

Khor, M. (2000). 'Rethinking Liberalisation and Reshaping the WTO', Presentation at the World Economic Forum, Davos. https://www.iatp.org/sites/default/files/Rethinking Liberalisation_and_Reshaping_the_WT.htm

Khor, M. (2001). 'Rethinking Globalisation: Critical Issues and Policy Choices', Zed Books. pp.16-38

Lake, D. (2004). "Hiearchy in International Relations: Authority, Sovereignity, and the New Structure of World Politics", Paper Presented at the American Political Science Association (ASPSA) Annual Meeting.

Leroux, M. (2017). "Trade rules that would mean no tariffs for decade", The Times of 21 March. https://www.thetimes.co.uk/article/trade-rules-that-would-mean-no-tariffsfor-decade-s0nf2p5z6. 
Vol. 7, No. 1 Igwe: WTO, A Multilateral Trade Institution or a Parallel Organisation...

Martin, W. \& P. Messerlin (2007). 'Why Is it so Difficult? Trade Liberalisation Under the Doha Agenda' in Oxford Review of Economic Policy 23(3):347-366.

Miller, T. \& D. Markheim (2008). 'Trade Liberalization Continuing Despite Doha impasse, the Heritage Foundation. at https://www.heritage.org/trade/report/tradeliberalization-continuing-despite-doha-impasse

Milner, C.R. (2006).'Making NAMA work: supporting adjustment and development' in The World Economy 29:1409-1422.

Morris, C. (2019). "Gatt 24: Would obscure trade rule help with no-deal Brexit? Reality Check Correspondent. BBC News. 24 June. https://www.bbc.co.uk/news/uk-4721 6870

Mortished, C. (2004). 'End to Years of Deadlock', The Times, Monday August 2.

Odell, J.S. (2005). 'Chairing a WTO Negotiation' in Journal of International Economic Law 8(2):425-448.

Ostry, S. (2002). 'The Uruguay Round North - South Grand Bargain: Implications for Future Generations', in D.M. Kennedy \& J.D. South Wick (eds.) The Political Economy of International Trade Law: Essays in Honour of Robert E. Hudec. Cambridge: Cambridge University Press.

Powell, R. (1991). "Absolute and Relative Gains in Imternational Relations Theory", in The American Political Science Review 85(4): 1303- 1320,

Prakash, A. \& J. A. Hart, (eds.). ((200). Coping With Globalisation. London: Routledge.

Preeg, E. H. (1970). Traders and Diplomats: An Analysis of the Kennedy Round of Negotiations under the General Agreement on Tariffs and Trade. Washington, D.C.: Brookings Institution

Rodrik, D. (1992). 'The Limits of Trade Policy Reform in Developing Countries - The Journal of Economic Perspectives' in The Journal of Economic Perspectives 6(1):87-105.

Rolland, S. E. (2007). 'Developing Country Coalitions at the WTO: In Search of Legal Support', in Harvard International Law Journal 48(2):483-551.

Sage, A. (2004). 'Wealthy Countries May End Farmers' Subsides', The Times, Monday, August 10-11.

Sander, H. \& A. Inotai (eds.) (1996). World Trade after the Uruguay Round', Prospects and Policy Options for the Twenty-First Century. London and New York: Routledge..

Schneider, G. (2005). 'Capacity and Concessions: Bargaining Power in Multilateral Negotiations' in Millenium 33(3): 665- 689

Sjostedt, G. (1986). 'Negotiating the Uruguay Round of the General Agreement on Tariffs and Trade. In I. W. Zartman (ed.) International Multilateral Negotiation. Approaches to the Manadement of Complexity, pp. 44-69. San Francisco: JosseyBass Publishers.

Steger, D.P. (2008). 'Introduction to the Mini-Symposium on Transparency in the WTO' in Journal of International Economic Law 11(4):705-826.

Steinberg, R. (2002). "In the Shadow of Law or Power? Consensus-based bargaining in the GATT/WTO" in International Organisation 56(2):339-374.

Steward, T.P. (ed.) (1992) .(ed.) (1992). 'The GATT Uruguay Round, A Negotiating History (1986 - 1992)' Commentary, Volume 2. Boston: Kluwer.

Stewart, T.P. (ed.) (1999). 'The GATT Uruguay Round'. A Negotiating History (19861994) Vol. IV: The End Game (Part 1) (The GATT Uruguay Round: A Negotiating History (1986-1992)). Kluwer Law International, pp.157-574

Stiglitz, J. (2000). Globalization and Its Discontents. New York: WW Norton Co

Stiglitz, J. E. \& Charlton, A. (2005). 'Fair Trade For All' How Trade can Promote Development. Oxford: Oxford University Press. 
Tallberg, J. (2006). The Power of the Chair: Formal Leadership in International cooperation. : Paper Prepared for the Third Pan-European Conference on EU Politics, Istanbul. http://citeseerx.ist.psu.edu/viewdoc/download?doi=10.1.1.482.6005\&re $\mathrm{p}=$ rep1\&type $=\mathrm{pdf}$

The Warwick Commission (2007). The Multilateral Trade Regime: Which Way Forward?. The Report of the First Warwick Commission, The University of Warwick.

Thomas, S. \& S. Canagarajah. (2002). 'Poverty in a Wealthy Economy: The case of Nigeria', International Monetary Fund Working Paper, WP/02/114.

UNCTAD (2000). Positive Agenda and Future Trade Negotiations, Geneva: United Nations Conference on Trade and Development

Veiga, P.M. (2005). 'Brazil and the G-20 Group of Developing Countries' in Managing the Challenges of the WTO Participation: Case Study 7.

Watal, J. (2000). 'Developing Countries' Interests in a Development Round', in J. J. Schott, (ed.), The WTO after Seattle, Peterson Institute for International Economics, at pp.70-85

Wilkinson, R. \& J. Scott. (2008). 'Developing Country Participation in the GATT: A reassessment" in World Trade Review 7(3):473-510

Wilkinson, R., Erin, H. \& J. Scott (2014). Development Agenda and why it Matters. 10 September: 1032-1050. https://www.tandfonline.com/doi/abs/10.1080/01436597.20 14.907726

Wilkinson, R., Erin, H. \& J. Scott. (2016). "The WTO in Nairobi: The Demise of Doha Development Agenda and the Future of the Multilateral Trade System" in Global Policy 7(2): 247-255.

Winham, G.R. (1986). International Trade and the Tokyo Round Negotiation. Princeton, N.Y.: Princeton University Press.

Winham, G. R. (1998). 'Explanations of Developing Country Behaviour in the GATT Uruguay Round Negotiation' in World Competition 21:109-134.

Wolf, R. (2004). 'Informal Political Engagement in the WTO: Are Mini- Ministerials a Good Idea?' in J.M Cutis \& Dan Ciuriak (eds.) Trade Policy Research Canada 2791.

Wolf, R. (2006). "NewGroups in the WTO Agricultural Trade Negotiations: Power, Learning and Institutional Design", Canadian Agricultural Trade Policy Research Network. DOI: 10.22004/ag.econ.24160

Wolf, R. (2007). 'Can the Trading System be Governed? Institutional Implications of the WTO's Suspended Animation, The Centre for International Governance and Innovation, Working Papers No. 30, September. http://www.cigionline.org,

Wood, V. (2019). "what is GATT 24: What is the WTO clause at the centre of Andrew Neil's grilling of Boris Johnson." The Independent 13 July. https://www.independe nt.co.uk/news/uk/politics/gatt-24-brexit-boris-johnson-andrew-neil-wto-no-deala9003211.html

WTO (1992). Report of Committee on Subsides and Countervailing Measures, GATT Doc. No. 4 6762, reprinted in GATT, BISD $37^{\text {th }}$ Supp. at 312.

WTO (1994). The Preamble, Marrakesh Agreement Establishing the World Trade Organisation, April 15, 1867 U.N.T.S. 154 [hereinafter Marrakesh Agreement].

WTO (1994a). Agreement on Implementation of Article VI of the General Agreement on Tariffs and Trade, page 145 (Anti-dumping Agreement). https://www.wto.org/engli sh/docs_e/legal_e/19-adp.pdf

WTO (1996). WTO Rules of Procedure for Ministerial and General Council Meetings', Document No. WT/L/161, 25 July. 
Vol. 7, No. 1 Igwe: WTO, A Multilateral Trade Institution or a Parallel Organisation...

WTO (1998). Trade Policy Review of India Report by the Secretariat WTO Document WT/TPR/S/33, dated 5 March.

WTO (2001a). Implementation-Related Issues and Concerns, WTO General Council Document JOB (01)/14, 20 February; and Compilation of Outstanding Implementation Issues Raised by Members, WTO Document JOB (01)/152/Rev. 1, 27 October.

WTO (2001b). World Trade Organisation: Doha WTO Ministerial Conference, WT/MIN(01)DEC/1, 9-13 November 2001, adopted on 14 November. http://www. wto.org/english/thewto_e/minist_e/min01_e/mindecl_e.htm

WTO (2001c) WTO Annual Report. http://ctrc.sice.oas.org/TRC/WTO/Annual_Publica tions/anrep01_e.pdf

WTO (2002). Oil Seeds Disputes - Chile Price Band System and Safeguard Measures Relating to Certain Agricultural Products, WTO, WT/DS207/R, 3 May.

WTO (2004). The Sutherland Report and the Warwick Report: Sutherland Peter et al., The Future of the WTO: Addressing Institutional Challenges in the New Millennium, Report of the Consultative Board to the Director-General Supachai Panitchpakdi, Geneva.

WTO (2004a). WTO Doha Development Agenda of the 'July Package', The General Council's Post-Cancun Decision, 1 August, WT/L/579. http://www.wto.org/English/ tratop_e/dda_e/ddadraft_31jul04_e.pdf

WTO (2005). ICTSD, 'Agriculture negotiations at the WTO: the July package and beyond', Quarterly Intelligence Report, 12 April.

WTO (2006). Transparency Mechanism for Regional Trade Agreements, Council Decision of 14 December 2006

WTO (2017). Recent Development in Regional Agreements. WTO, July - December 2017.

Zartman, I.W. (1994). "Two's Company and More's a Crowd: The Complexities of Multilateral Negotiation" in I.W. Zartman (ed.) International Multilateral Negotiations, pp. 1-10, San Francisco, Cal.: Jossey-Bass Publishers. 